\title{
Meteorological variables associations and the occurrence of covid-19 in the city of São Paulo, Brazil
}

Several studies evaluate the association between meteorological variables and cases of respiratory diseases, such as acute respiratory syndrome (SARS) and influenza. Since the emergence of the new coronavirus (SARS-CoV-2), researchers from all over the world have joined forces to study the influence of demographic, anthropogenic and climatic aspects on the incidence of new cases of the disease. According to this, the objective of this study is to present a preliminary assessment of the associations between confirmed cases and deaths caused by the disease COVID-19, in the first days of the contamination in the city of São Paulo-Brazil, with the meteorological variables temperature, relative humidity, atmospheric pressure, and wind speed. Data on the daily numbers of contamination cases and death from COVID-19 in addition to meteorological variables were collected from February 26, 2020, to April 6, 2020. Associations were measured using Spearman's correlation coefficient and daily incidence rates (IRR), with their $95 \%$ confidence intervals (CI), for each meteorological factor was estimated using the generalized linear regression model with a negative binomial distribution. It was observed temperature and relative humidity are important variables to identify meteorological conditions associated with the number of deaths and contamination by the COVID-19. Extreme events may be related to an increase in the daily numbers of new cases and deaths at the beginning of contamination in the city of São Paulo.

Keywords: Generalized Linear Regression Model; Relative Humidity; SARS-CoV-2; Temperature.

\section{Associação de variáveis meteorológicas e ocorrência de covid-19 na cidade de São Paulo, Brasil}

\begin{abstract}
Vários estudos avaliam a associação entre variáveis meteorológicas e casos de doenças respiratórias, como síndrome respiratória aguda (SARS) e influenza. Desde o surgimento do novo coronavírus (SARS-CoV-2), pesquisadores de todo o mundo uniram forças para estudar a influência de aspectos demográficos, antropogênicos e climáticos na incidência de novos casos da doença. Nesse sentido, o objetivo deste estudo é apresentar uma avaliação preliminar das associações entre os casos confirmados e de óbitos causados pela COVID-19, nos primeiros dias da contaminação na cidade de São Paulo-Brasil, com variáveis meteorológicas, entre elas, temperatura, umidade relativa, pressão atmosférica e velocidade do vento. Os dados sobre o número diário de casos confirmados e de óbitos do COVID19 , além de variáveis meteorológicas, foram coletados de 26 de fevereiro de 2020 a 6 de abril de 2020 . As associações foram medidas usando o coeficiente de correlação de Spearman e as taxas de incidência diária (TIR), com seus respectivos intervalos de $95 \%$ de confiança (IC) para cada fator meteorológico foram estimados usando o modelo de regressão linear generalizada com distribuição binomial negativa. Observou-se que temperatura e umidade relativa do ar são variáveis importantes para identificar condições meteorológicas associadas ao número de mortes e casos confirmados de COVID-19. Eventos extremos podem estar relacionados a um aumento no número diário de novos casos e mortes no início da contaminação na cidade de São Paulo.
\end{abstract}

Palavras-chave: Modelo de Regressão Linear Generalizada; Umidade Relativa; SARS-CoV-2; Temperatura.

Topic: Epidemiologia e Saúde Ambiental

Reviewed anonymously in the process of blind peer.
Received: 03/08/2020

Approved: $18 / 09 / 2020$
Sergio Augusto Rodrigues (iD

Universidade Estadual Paulista Júlio de Mesquita Filho, Brasil http://lattes.cnpq.br/6872765214523974 http://orcid.org/0000-0002-2091-2141 sergio.rodrigues@unesp.br

\section{Alexandre Dal Pai (iD)}

Universidade Estadual Paulista Júlio de Mesquita Filho, Brasil http://lattes.cnpq.br/9708248454957558 http://orcid.org/0000-0002-1283-901X

dal.pai@unesp.br

Rejane Maria Tommasini Grotto (iD)

Universidade Estadual Paulista Júlio de Mesquita Filho, Brasil http://lattes.cnpq.br/7788448564326585

http://orcid.org/0000-0002-4035-9486

rejane.grotto@unesp.br

DOI: 10.6008/CBPC2179-6858.2020.005.0024
Valéria Cristina Rodrigues Sarnighausen (iD

Universidade Estadual Paulista Júlio de Mesquita Filho, Brasil

http://lattes.cnpq.br/0734394320595118

http://orcid.org/0000-0003-3943-0211

valeria.sarnighausen@unesp.br

\section{Referencing this:}

RODRIGUES, S. A.; DAL PAI, A.; GROTTO, R. M. T.; SARNIGHAUSEN, V. C. R.. Meteorological variables associations and the occurrence of covid-19 in the city of São Paulo, Brazil. Revista Ibero Americana de Ciências Ambientais, v.11, n.5, p.249-260, 2020. DOI: http://doi.org/10.6008/CBPC2179-6858.2020.005.0024 


\section{INTRODUCTION}

Because of the new coronavirus, the world has faced an unprecedented epidemic in recent months, with impacts on social, political, and economic sectors, but mainly in the health sector. This will certainly cause significant changes in relations between countries and people. Coronavirus ( $\mathrm{CoV}$ ) is a family of viruses that cause respiratory infections and is named because they have the shape of a crown when viewed on microscopy images. They cause respiratory, enteric, hepatic and neurological problems in several animals and show tendencies of genetic recombination and high mutation rates, which allow them to adapt to new hosts and environments (LAl et al., 1997).

Two types of coronavirus have attracted attention in the past two decades: SARS-CoV (Severe Acute Respiratory Syndrome) and MERS-CoV (Middle East Respiratory Syndrome). SARS-CoV originated in 20022003 in Guangdong province, southern China, and was responsible for 774 (CHAN-YEUNG et al., 2003). MERSCoV, originating in the Middle East in 2012-2013, already accounts for 858 deaths (WHO, 2019). But none of them are as lethal and aggressive as the new coronavirus that plagues world society today. On 12/31/2019, WHO recognized this new disease as SARS-Cov-2 or popularly COVID-19 (WHO, 2020a).

One of the major obstacles to controlling the SARS-CoV-2 pandemic is its high person-to-person transmission and its viability in the environment. The most common symptoms of COVID-19 are fever, dry cough, pneumonia, and in more severe cases, progressive respiratory failure with damage to the alveoli and death. People with a history of pre-existing diseases and/or comorbidities are more susceptible to the disease (HUANG et al., 2020).

In early January 2020, Chinese researchers isolated and identified SARS-CoV-2 using samples collected from patients in Wuhan, China, the epicenter of the disease. After verifying human-to-human transmission (WANG et al., 2020a) and increasing numbers of cases on a global scale due to its high transmission power, WHO declared a pandemic state in mid-March 2020 (MA et al., 2020; WHO, 2020a). Despite countries adopting measures such as social isolation and mass testing of the population to reduce the transmission of the disease, as of April 7, 2020, there were already more than 1.2 million confirmed cases and more than 72 thousand deaths worldwide (WHO, 2020b).

Researchers from all over the world have joined forces to study COVID-19, relating cases of the disease to demographic, anthropogenic, and climatic aspects. Research findings show that the virus can survive for up to 9 days on smooth surfaces, depending on environmental conditions (KAMPF et al., 2020). Chinazzi et al. (2020), on the other hand, indicate a reduction in the virus transmission rates when adopting travel restriction policies. Ahmadi et al. (2020) emphasize the importance of understanding the influence of human and environmental parameters in COVID to guide strategic actions to combat the disease, which may vary from country to country. Zambrano-Monserrate et al. (2020) relate the impact of COVID-19 on the emission of greenhouse gases from studies carried out with the Copernicus Sentinel-5P satellite.

Studies also point to the importance of associating the number of COVID-19 cases with climatic variables such as temperature, relative humidity, wind speed, solar radiation and precipitation for different 
locations (GUPTA et al., 2015; QU et al., 2017; AHMADI et al., 2020; Ql et al., 2020; BASHIR et al., 2020; PRATA et al., 2020; SOBRAL et al., 2020; OLIVEIROS et al., 2020; WANG et al., 2020b). However, different climatic conditions and different statistical tools used in the analyzes produced controversial results for climaticCOVID correlations. So, further studies are required to better understand the correlation of COVID-19 cases with climatic variables, mainly for tropical climates.

The first confirmed case of contamination by the new coronavirus (COVID-19) in Brazil occurred in the city of São Paulo, on February 26, 2020 (BRASIL, 2020), being a 61-year-old man, who was traveling to Italy, in the Lombardy region. From the first case until April 6, the country recorded 4,866 cases of the disease and 304 deaths, according to the Center for Epidemiological Surveillance from São Paulo State Health Department (SEADE, 2020). The epicenter of the epidemic in Brazil is the city of São Paulo, with $36 \%$ of the cases of contaminated and about $40 \%$ of the deaths until the analyzed data.

Thus, the objective of this work is to present a preliminary assessment of the associations between confirmed cases and deaths reported for COVID-19 with meteorological variables, in addition to checking possible effects of the variables temperature, relative humidity, and atmospheric pressure on the daily number of deaths. The study focuses on the beginning of transmission in the city of São Paulo, in order to identify possible patterns of dissemination and lethality related to the disease.

\section{METHODOLOGY}

The city of São Paulo, with about 12.25 million inhabitants (IBGE, 2019), is located $770 \mathrm{~m}$ above average sea level and $60 \mathrm{~km}$ west of the Atlantic Ocean (Figure 1). The climate, typical of subtropical regions of Brazil, is characterized by a dry winter during June-August and a humid summer during the months of December to March. According to Codato et al. (2008), the minimum values of temperature and relative humidity of the daily air occur in July and August (16ㅇ and $74 \%$, respectively), and the minimum monthly precipitation occurs in August $(35 \mathrm{~mm}$ ). The maximum daily average of air temperature occurs in February $(22.5 \circ)$ and maximum daily relative humidity occurs from December to January and from March to April (80\%). The maximum value of total monthly precipitation occurs in February $(255 \mathrm{~mm})$. The shortest and longest daylight duration is 10.6 hours (June) and 13.4 hours (December), respectively, when the sun reaches its maximum solar elevation of 540 and 89 o. The diurnal evolution of surface winds in the city of São Paulo is systematically affected by the penetration of the sea breeze and the topography. Despite the high altitude and distance from the ocean, the sea breeze penetrates São Paulo in about $50 \%$ of the days of the year (OLIVEIRA et al., 2003).

The meteorological variables air temperature, relative humidity, atmospheric pressure and wind speed were provided by the National Institute of Meteorology (INMET, 2020) in the period from 02/17/2020 to $04 / 06 / 2020$. The measurements were made in the hourly partition by the automatic weather station SESCInterlagos, located in the city of São Paulo (Latitude -23.72450 , Longitude -46.67750 and Altitude $771 \mathrm{~m}$ ). The daily values were calculated using a computational routine developed in the Origin software (Microlabs TM). 


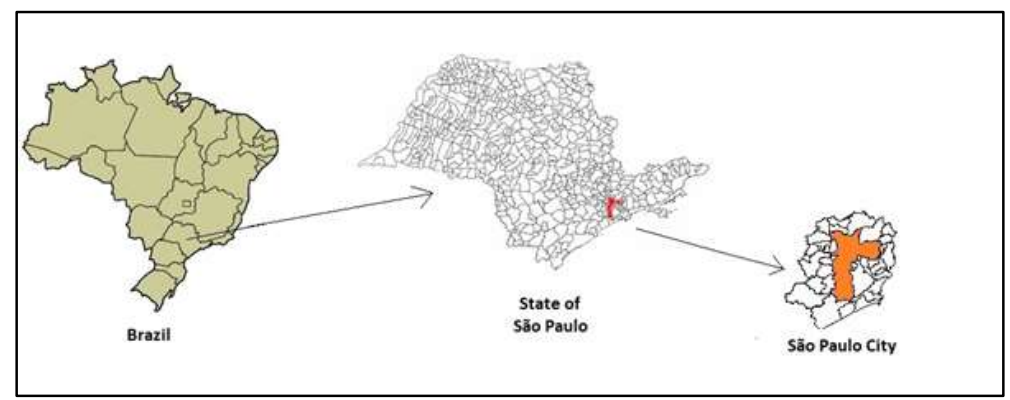

Figure 1: Map of Brazil with state divisions showing the sampling location (São Paulo City).

The number of confirmed cases and deaths by COVID-19 were obtained from the Epidemiological Surveillance Center "Prof. Alexandre Vranjac" from the São Paulo State Health Secretariat, available on the website of the State Foundation for Statistical data (SEADE, 2020). The period between February 26, 2020, to April 6, 2020 (41 days) was used to account for the daily number of confirmed cases. The period between March 17, 2020, to April 6, 2020 (21 days) was used to account for the daily number of deaths.

Initially, the descriptive statistics of the variables were calculated. Then, the associations between the meteorological variables and the number of confirmed cases and deaths by COVID-19 were measured using Spearman's correlation coefficient, also considering lags of 0, 5, 10 and 15 days in the meteorological variables. A generalized linear regression model with a negative binomial distribution, which takes into account the problem of overdispersion, was used to estimate the daily incidence rate ratio (IRR) of new cases and deaths of COVID-19 and its 95\% confidence intervals $(\mathrm{CI})$ by temperature, relative humidity, barometric pressure, and wind speed. A 5\% level of significance was used for inferential analyzes. The R-Gui version 3.6.3 ( $R$ CORE TEAM, 2020) was used for all statistical analyzes and the "mgcv" package was used to adjust the models.

\section{RESULTS}

\section{Descriptive analysis}

Table 1 contains the descriptive analysis of data related to meteorological variables and the periods of the first confirmed cases of contamination (February 26 to April 6) and death (March 17 to April 6 ). 41 daily counting measures were taken for contamination cases and 21 measurements for death numbers, and their corresponding daily meteorological variables. Temperature and relative humidity of the air ranged from 14 to $32.8^{\circ} \mathrm{C}$ and from 34 to $98 \%$, respectively. Atmospheric pressure varied from 919.9 to $932.7 \mathrm{hPa}$. The number of new contamination cases, reported each day in the city of São Paulo, ranged from zero to 822. The variation in new cases of deaths was from zero to 41.

Table 1: Descriptive analysis of meteorological variables and contamination and death counts.

\begin{tabular}{llllllll}
\hline Variable & $\mathbf{n}$ & Mean (SD) & Min & Max & Median & P25 & P75 \\
\hline Tmean $\left({ }^{\circ} \mathrm{C}\right)$ & 41 & $20.41(1.98)$ & 17.23 & 24.67 & 20.59 & 18.70 & 21.59 \\
$\operatorname{Tmax}\left({ }^{\circ} \mathrm{C}\right)$ & 41 & $25.88(3.33)$ & 19.60 & 32.80 & 25.80 & 23.50 & 27.80 \\
$\operatorname{Tm} i n\left({ }^{\circ} \mathrm{C}\right)$ & 41 & $17.08(1.63)$ & 14.00 & 21.20 & 17.00 & 15.60 & 18.30 \\
RHmean $(\%)$ & 41 & $83.57(5.85)$ & 71.75 & 93.29 & 82.96 & 80.58 & 86.58 \\
RHmax $(\%)$ & 41 & $95.76(1.88)$ & 89.00 & 98.00 & 96.00 & 95.00 & 97.00 \\
RHmin $(\%)$ & 41 & $58.24(11.27)$ & 34.00 & 80.00 & 58.00 & 50.00 & 63.00 \\
Pmean $(\mathrm{hPa})$ & 41 & $927.80(2.21)$ & 921.83 & 931.54 & 928.31 & 927.19 & 929.13 \\
\hline
\end{tabular}




\begin{tabular}{lllllll} 
Pmax (hPa) & 41 & $929.67(1.84)$ & 924.10 & 932.70 & 929.60 & 929.10 \\
Pmin(hPa) & 41 & $926.10(2.54)$ & 919.90 & 930.40 & 926.90 & 930.60 \\
WS (m/s) & 41 & $2.11(0.56)$ & 1.23 & 3.56 & 2.04 & 927.70 \\
Cases new & 41 & $118.68(195.15)$ & 0.00 & 822.00 & 45.00 & 2.45 \\
Dead new & 21 & $14.48(11.00)$ & 0.00 & 41.00 & 10.00 & 7.00 \\
\hline
\end{tabular}

Figure 2 shows the temporal evolution of the meteorological variables temperature, relative humidity, and atmospheric pressure and the sequences of daily numbers of deaths. The peaks and valleys of temperature curves are accompanied by variations in the number of deaths. As temperatures rise, the number of deaths decreases. For relative humidity, a decrease in their values is accompanied by an increase in the number of deaths.

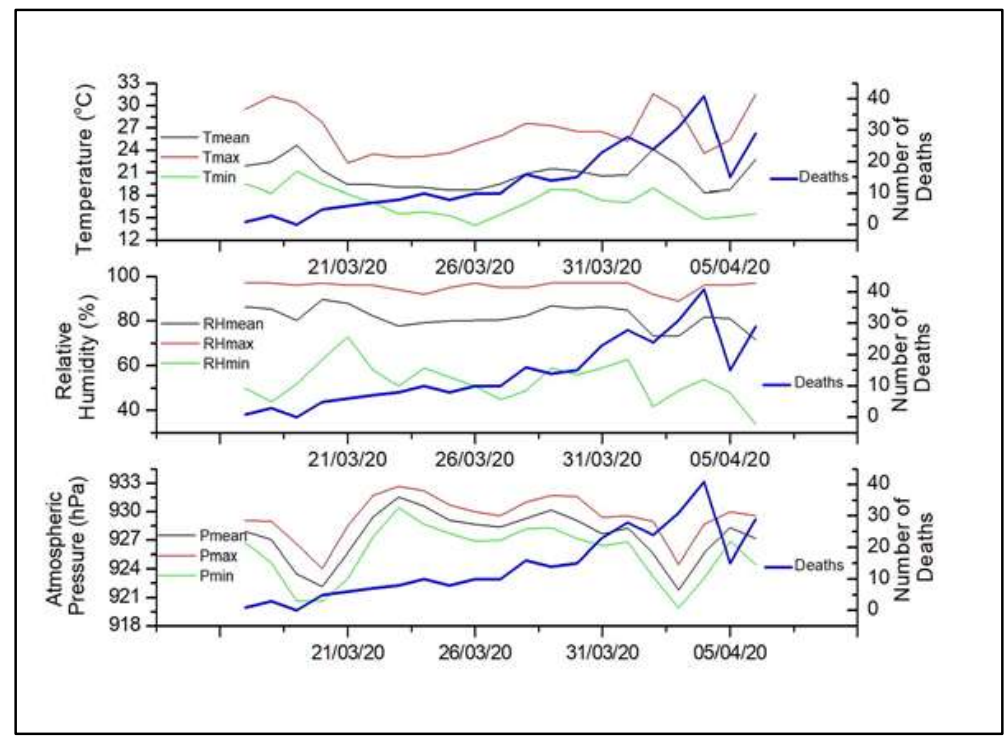

Figure 2: Relationship between maximum, average and minimum values of meteorological variables and daily number of deaths.

\section{Analysis of associations between new cases and deaths with meteorological factors}

Table 2 shows Spearman's associations between meteorological variables and daily numbers of deaths and contaminants, at different times, considering lags of $0,5,10$, and 15 days. The mean temperature shows a positive and significant correlation at lags zero and 5 for new cases of contamination $(r=0.348$ and 0.349 , respectively) and for maximum temperature $(r=0.442$ and 0.445 , respectively). For relative humidity (average, maximum and minimum), a negative correlation is observed with the number of contaminated cases at lag zero $(r=-0.555,-0.314$ and -0632$)$, while at lag 5 , only RHmean and RHmin were significant $(r=-$ 0.463 and -0.654$)$. These associations may indicate that days with higher average temperatures also have more confirmed cases of COVID-19, as well as days with lower relative humidity (Table 2).

For Tmin in lag 10, it is observed a negative and significant correlation with the number of new cases $(r=-0.288)$, as well as for mean, maximum and minimum air relative humidity $(r=-0.411,-0.495$ and -0.276 respectively). This may indicate that 10 days after lower Tmin and UR conditions, the number of contamination cases increases. Also in lag 10, it is observed that barometric pressures (mean, maximum and minimum) showed significant and positive correlations with the number of confirmed cases $(r=0.332,0.341$ and 0.301), whereas in lag zero, only the minimum pressure showed a low negative association with the 
number of cases $(r=-0.292)$. The variables RHmean, RHmax and RHmin have a negative and significant correlation for most of the lags in relation to the numbers of new cases, which is not observed for new cases of deaths, except for the lag 15.

Table 2: Spearman's correlation coefficients between meteorological variables (in different lags) and new cases of death and contamination.

\begin{tabular}{|c|c|c|c|c|c|c|c|c|}
\hline \multirow[t]{2}{*}{ Variable } & \multicolumn{4}{|c|}{$\begin{array}{l}\text { New Cases } \\
n=41\end{array}$} & \multicolumn{4}{|c|}{$\begin{array}{l}\text { New Dead } \\
n=21\end{array}$} \\
\hline & LO & $\mathbf{L 5}$ & L10 & L15 & LO & L5 & L10 & L15 \\
\hline Tmean & $0.348 *$ & 0.349* & -0.072 & 0.098 & -0.074 & $-0.457^{*}$ & -0.320 & $0.758 *$ \\
\hline Tmax & $0.442 *$ & $0.445^{*}$ & 0.028 & 0.126 & 0.087 & $-0.425^{* *}$ & -0.332 & $0.625^{*}$ \\
\hline Tmin & 0.025 & 0.121 & $-0.288 * *$ & 0.052 & $-0.421 * *$ & $-0.379 * *$ & -0.204 & $0.811^{*}$ \\
\hline RHmean & $-0.555^{*}$ & $-0.463^{*}$ & $-0.411^{*}$ & -0.243 & -0.330 & 0.099 & -0.239 & -0.208 \\
\hline RHmax & $-0.314 *$ & -0.240 & $-0.495^{*}$ & -0.208 & -0.145 & 0.323 & -0.121 & -0.258 \\
\hline RHmin & $-0.632 *$ & $-0.654^{*}$ & $-0.276 * *$ & -0.187 & -0.186 & -0.006 & -0.198 & $-0.402 * *$ \\
\hline Pmean & -0.209 & 0.179 & $0.332 *$ & 0.026 & -0.090 & 0.301 & 0.180 & -0.338 \\
\hline Pmax & -0.181 & 0.124 & $0.341 *$ & 0.040 & 0.036 & 0.346 & 0.211 & $-0.411^{* *}$ \\
\hline Pmin & $-0.292 * *$ & 0.133 & $0.301^{* *}$ & -0.006 & -0.062 & 0.253 & 0.097 & $-0.515^{*}$ \\
\hline WS & $-0.367^{*}$ & -0.203 & 0.223 & -0.104 & -0.142 & 0.160 & $0.389 * *$ & $-0.426 * *$ \\
\hline
\end{tabular}

* Significant $(p<0.05) ; * *$ Significant $(p<0,10)$

In lag 10, the only meteorological variable that showed a significant correlation with the number of deaths was the wind speed $(r=0.389)$. At lags zero and 5 , negative correlations between the number of deaths and air temperature are observed $(r=-0.421$ at lag zero for Tmim and $r=-0.457,-0.425$ and -0.379 at lag 5 for Tmean, Tmax and Tmim, respectively).

For lag 15, the number of deaths showed significant positive correlations with Tmean $(r=0.758)$, $\operatorname{Tmax}(r=0.625), \operatorname{Tmin}(r=0.811)$ and significant negative correlations with RHmin $(r=-0.402), \operatorname{Pmax}(r=-$ $0.411)$ and wind speed $(r=-0.426)$. Evaluation in lagged times can be important due to the virus incubation time, which is linked to the manifestation of the disease.

The number of deaths was computed from the confirmation of death due to the virus and, therefore, the data are more reliable when compared to the numbers of contaminated cases. For contaminated cases, the delay in exam results and the lack of mass testing can generate uncertainty and fail to portray the reality of the day. It is also noteworthy that the results point to possible associations between variations in temperature, relative humidity and barometric pressure with the number of deaths for lag zero. However, the time lag for manifestation, complications and disease outcome must be taken into account.

\section{Effect of temperature, relative humidity, pressure and wind speed on COVID-19 mortality}

Tables 3 and 4 show the results of the negative binomial regression model, which was adjusted to assess the effects of meteorological variables in new daily cases and in daily mortality from COVID-16, respectively. The IRR indicates possible variations in daily cases or daily mortality with the unit increase in each meteorological variable in different lags.

In relation to the new cases, the mean daily temperature and relative humidity were significantly associated with an increase in mortality from COVID-19, while maximum temperature, relative humidity (maximum and minimum) and wind speed were significantly associated with a decrease in mortality, considering the effects of other factors. Thus, an increase of one unit in temperature was associated with an 
increase in the count of new cases by COVID-19 at lag zero (IRR of 32 [95\% Cl: 3.9; 273.1]), as well as an increase of one unit in RHmean increased by 1.5 [95\% Cl: 1.0; 2.2] times in the number of cases. However, the unitary increase in maximum temperature, relative humidity (maximum and minimum) and wind speed was associated with a reduction in the number of covid-19 cases at lags zero (Tmax, RHmin and WS), 5 (Tmax and RHmin), 10 (RHmax) and 15 (RHmax and RHmin). There was a greater reduction in confirmed cases with an increase in Tmax (variation of $-94 \%$, that is, IRR $=0.06$ [95\% Cl: $0.02 ; 0.21]$ ) at lag zero and RHmax (variation of $-51 \%$ in cases, with an IRR of 0.49 [95\% $\mathrm{Cl}: 0.3 ; 0.79]$ ) at lag 15 .

Table 3: Estimated coefficients, $p$-value, incidence rate ratio (IRR) and $95 \%$ confidence interval obtained from the Negative Binomial Regression adjusted for lags zero, 5, 10 and 15 days - number of confirmed cases $\mathrm{x}$ meteorological variables.

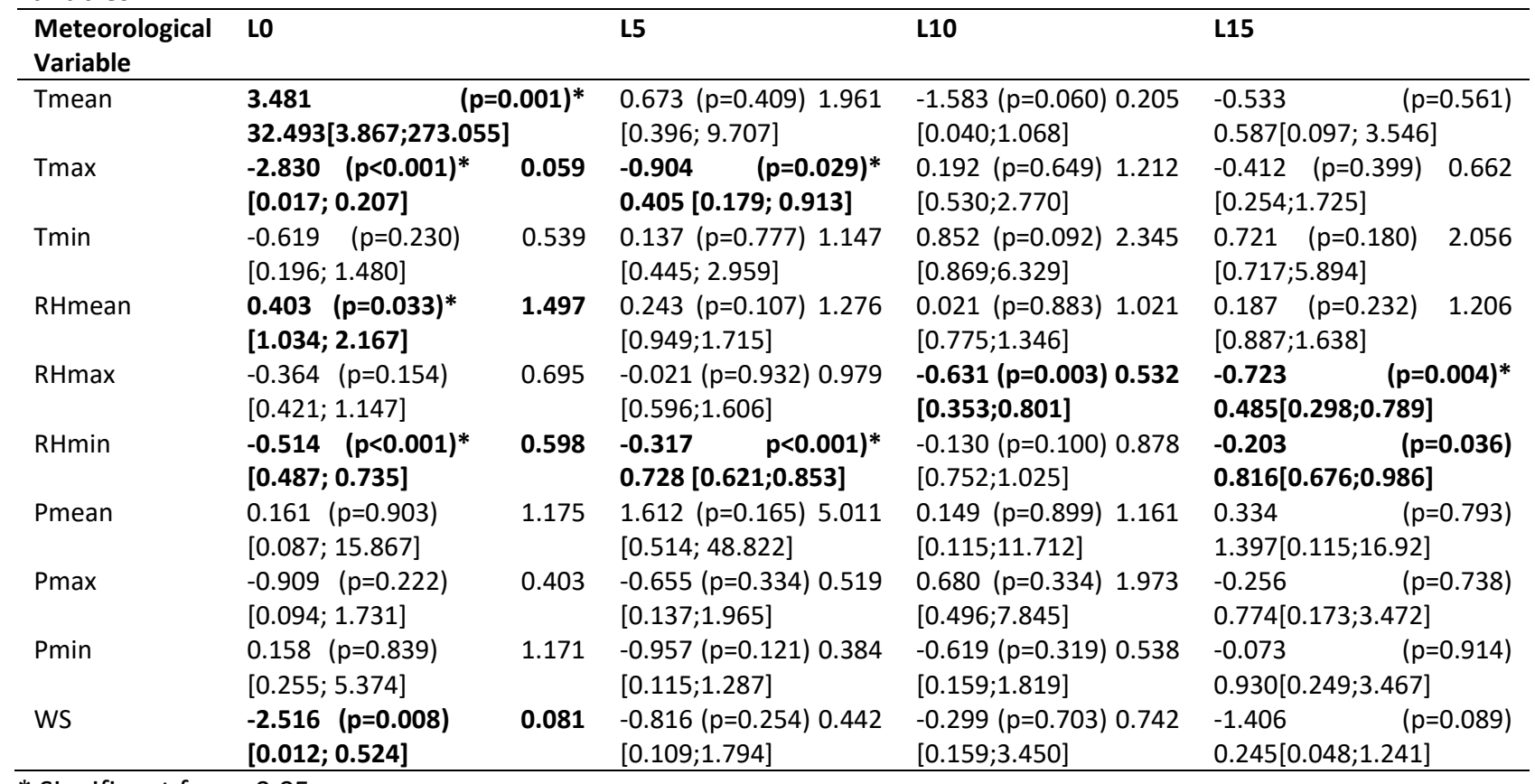

* Significant for $p<0.05$

Regarding the incidence of deaths from COVID-19, for lag zero, it is observed that mean temperature, mean relative humidity and atmospheric pressure (maximum and minimum) showed positive associations, while minimum temperature, maximum relative humidity, maximum pressure and speed of winds showed a negative relationship, considering the effects of other factors. Tmean (IRR of 5 [95\% Cl: 2.2; 11.3]) and Pmax (IRR of 3.31 [95\% CI: [2.1; 5.3]) contributed to an increase in cases of death with a positive variation in their values. On the other hand, the variables Pmean (IRR $=0.16$ [95\% Cl: $0.07 ; 0.36])$ and $\operatorname{Tmin}(0.24$ [95\% Cl: 0.16 ; 0.38]) contributed to the decrease in mortality, with mean reductions of $84 \%$ and $76 \%$, respectively.

Considering the lags 10 or 15 , it is clear that the increase in the number of deaths was associated with an increase in the mean pressure (IRR = 7,389 [1,137; 48,009] for lag 10 and IR = 3,788 [95\% CI: 1,093; 13,132] for lag 15) and minimum temperature (IRR $=2,399$ [95\% Cl: 1,248; 4,610] for lag 10 and IRR = 1,674 [95\% Cl: 1,059; 2,647] for lag 15), while an increase in minimum pressure results in a reduction in deaths (IRR $=0.321$ [95\% Cl: $0.138 ; 0.745]$ for lag 10 and IRR $=0.485$ [95\% Cl: $0.260 ; 0.905]$ lag 15 ). 
Table 4: Estimated coefficients, $p$-value, incidence rate ratio (IRR) and $95 \%$ confidence interval obtained from the Negative Binomial Regression adjusted for lags zero, 5, 10 and 15 days - number of deaths x meteorological variables.

\begin{tabular}{|c|c|c|c|c|c|c|c|}
\hline $\begin{array}{l}\text { Meteorological } \\
\text { Variables }\end{array}$ & LO & L5 & & L10 & & L15 & \\
\hline Tmean & $\begin{array}{l}1.610(p=<0.001) * 5.001 \\
{[2.217 ; 11.281]}\end{array}$ & $\begin{array}{l}0.613 \quad(p=0.213) \\
{[0.703 ; 4.840]}\end{array}$ & 1.845 & $\begin{array}{l}-0.744 \quad(p=0.144) \\
{[0.175 ; 1.289]}\end{array}$ & 0.475 & $\begin{array}{l}-0.083 \quad(p=0.848) \\
{[0.393 ; 2.153]}\end{array}$ & 0.920 \\
\hline Tmax & $\begin{array}{l}-0.462 \quad(p=0.065) 0.630 \\
{[0.386 ; 1.030]}\end{array}$ & $\begin{array}{l}-1.036 \quad(p=<0.001)^{*} \\
{[0.214 ; 0.588]}\end{array}$ & 0.355 & $\begin{array}{l}-0.486(p=0.119) \\
{[0.334 ; 1.133]}\end{array}$ & 0.615 & $\begin{array}{l}-0.213 \quad(p=0.376) \\
{[0.505 ; 1.295]}\end{array}$ & 0.808 \\
\hline Tmin & $\begin{array}{l}-1.421 \quad(p=<0.001)^{*} \\
0.241[0.156 ; 0.375]\end{array}$ & $\begin{array}{l}0.118 \quad(p=0.672) \\
{[0.651 ; 1.945]}\end{array}$ & 1.125 & $\begin{array}{l}0.875(p=0.009) * \\
{[1.248 ; 4.610]}\end{array}$ & 2.399 & $\begin{array}{l}0.515(p=0.027)^{*} \\
{[1.059 ; 2.647]}\end{array}$ & 1.674 \\
\hline RHmean & $\begin{array}{l}0.220(p=0.006) \\
1.247[1.065 ; 1.460]\end{array}$ & $\begin{array}{l}0.121 \quad(p=0.179) \\
{[0.946 ; 1.348]}\end{array}$ & 1.129 & $\begin{array}{l}0.061 \quad(p=0.462) \\
{[0.903 ; 1.250]}\end{array}$ & 1.063 & $\begin{array}{l}0.117 \quad(p=0.132) \\
{[0.965 ; 1.308]}\end{array}$ & 1.124 \\
\hline RHmax & $\begin{array}{l}-0.224(p=0.011) 0.800 \\
{[0.673 ; 0.950]}\end{array}$ & $\begin{array}{l}-0.024 \quad(p=0.864) \\
{[0.747 ; 1.277]}\end{array}$ & 0.977 & $\begin{array}{l}-0.185 \quad(p=0.113) \\
{[0.662 ; 1.044]}\end{array}$ & 0.831 & $\begin{array}{l}-0.198 \quad(p=0.116) \\
{[0.641 ; 1.050]}\end{array}$ & 0.821 \\
\hline RHmin & $\begin{array}{l}0.013(p=0.757) \\
1.013[0.933 ; 1.101]\end{array}$ & $\begin{array}{l}-0.184(p=<0.001)^{*} \\
{[0.765 ; 0.905]}\end{array}$ & 0.832 & $\begin{array}{l}-0.144(p=0.002)^{*} \\
0.866[0.791 ; 0.94\end{array}$ & & $\begin{array}{l}-0.085 \quad(p=0.055) \\
{[0.842 ; 1.002]}\end{array}$ & 0.918 \\
\hline Pmean & $\begin{array}{ll}-1.838 \quad(p=<0.001)^{*} \\
0.159[0.070 ; 0.362]\end{array}$ & $\begin{array}{lr}1.094 & (p \\
2.987[0.852 ; 10.477]\end{array}$ & .087) & $\begin{array}{l}2.000(p=0.036)^{*} \\
{[1.137 ; 48.009]}\end{array}$ & 7.389 & $\begin{array}{l}1.332(p=0.036)^{*} \\
{[1.093 ; 13.132]}\end{array}$ & 3.788 \\
\hline Pmax & $\begin{array}{l}1.191(p=<0.001) * 3.291 \\
{[2.061 ; 5.256]}\end{array}$ & $\begin{array}{l}-0.758 \quad(p=0.062) \\
{[0.212 ; 1.038]}\end{array}$ & 0.469 & $\begin{array}{l}-0.764 \quad(p=0.162) \\
{[0.160 ; 1.359]}\end{array}$ & 0.466 & $\begin{array}{l}-0.644 \quad(p=0.088) \\
{[0.251 ; 1.100]}\end{array}$ & 0.525 \\
\hline Pmin & $\begin{array}{l}0.738(p=0.002) 2.091 \\
{[1.317 ; 3.320]}\end{array}$ & $\begin{array}{l}-0.393 \quad(p=0.237) \\
{[0.352 ; 1.296]}\end{array}$ & 0.675 & $\begin{array}{l}-1.135(p=0.008)^{*} \\
{[0.138 ; 0.745]}\end{array}$ & 0.321 & $\begin{array}{l}-0.724(p=0.023)^{*} \\
{[0.260 ; 0.905]}\end{array}$ & 0.485 \\
\hline WS & $\begin{array}{l}-0.831 \quad(p=0.034) 0.436 \\
{[0.202 ; 0.939]}\end{array}$ & $\begin{array}{l}-1.791(p=<0.001)^{*} \\
{[0.069 ; 0.405]}\end{array}$ & 0.167 & $\begin{array}{l}-1.619(p=0.090) \\
{[0.030 ; 1.287]}\end{array}$ & 0.198 & $\begin{array}{l}-0.027 \quad(p=0.949) \\
{[0.424 ; 2.232]}\end{array}$ & 0.973 \\
\hline
\end{tabular}

* Significant for $\mathrm{p}<0.05$

\section{DISCUSSION}

Fluctuations in temperature, relative humidity, and atmospheric pressure were observed and may be related to the daily new cases and deaths by COVID-19, at the beginning of the contamination in the city of São Paulo-Brazil. Studies indicate that meteorological factors are associated with the annual incidence of influenza and other respiratory diseases. There is a higher incidence of respiratory disease contamination in conditions of temperature and relative humidity reduced, that facilitate the spread of aerosols that are carriers of viruses (JAAKKOLA et al., 2014; SUNDELL et al., 2016). Variations in temperature cause variations in air relative humidity and consequently in atmospheric pressure (PAULOSE et al., 2014), due to the convective processes of transporting heat and water vapor in the atmosphere. However, Lowen et al. (2007) indicate the higher relative humidity is related to minor contamination by viruses. The higher water concentration in the atmosphere promotes more likely to adherence to the virus, which increases its weight and facilitates its deposition by gravitational action. This causing the virus remaining in suspension in the atmosphere for less time.

Considering the occurrence of the disease symptoms attributed to COVID-19 appear a few days after the contagion, and therefore, the numbers may be correlated with the weather conditions of previous days, for lag zero the significant correlations may not portray the contamination process and symptom manifestation, however, positive associations of death cases with temperature and negative with humidity were also observed by Ma et al. (2020).

The negative associations of new cases with minimum temperature and relative humidity (average, maximum and minimum) and positive associations with atmospheric pressures (minimum, maximum and average), 10 days before confirmation, corroborate with some results from the literature on respiratory diseases (JAAKKOLA et al., 2014). Studies mention that the increase in temperature can cause a decrease in 
death numbers by COVID19 (SHI et al., 2020; FICETOLA et al., 2020), as the negative associations between the death numbers and Tmin, Tmax and Tmean for the lag 5.

The significant associations between the relative humidity (min, max and mean) and the new contaminated cases were negative, showing that for the analyzed data, the reduction of relative humidity increases the numbers analyzed, for all lags of up to 10 days. Air low humidity facilitates contamination by viruses due to reduced protection of the mucous membranes of the respiratory system (JO et al., 2017), which is an aggravating factor for both new cases and mortality.

However, the occurrences of respiratory viruses generally increase in humid seasons in countries with tropical climates. The same is observed in cold and dry seasons in countries with temperate climates, with average temperatures below $5^{\circ} \mathrm{C}$ (ROUSSEL et al., 2016), a condition that does not occur in most of the Brazilian territory. The causes of these respiratory diseases, such as influenza, are not yet totally understood (PECl et al., 2019). Even in the case of a tropical climate city, the reduction of relative humidity could aggravate the disease.

The low air relative humidity, characteristic of winter in countries with a temperate climate, allows better survival of the influenza virus and its transport via aerosols. However, the higher the air relative humidity, the conditions present in humid seasons in tropical countries, the greater the maintenance of the virus's physiological saline solution, which maintains it viable for dissemination (YANG et al., 2012; PECl et al., 2019).

Wind speed is also an important variable in terms of aerosol dissipation, heat, and humidity (PECl et al., 2019), so the higher the wind speed, the greater the aerosol dissipation power, facilitating the process contamination by virus. We obtained a negative and significant association between wind speed and death numbers, for lags zero and 5 . The same was observed related to new case numbers, in lag zero. These observations agree with the observed by Altamimi et al. (2020), that evaluated the influence of climatic factors on the incidence of respiratory syndrome by a coronavirus in the Middle East (MERS-CoV).

Considering the adjusted negative binomial regression results of the model (Table 3), to the zero lag, the $1^{\circ} \mathrm{C}$ increase in Tmean is associated with an increase of 32 times the number of cases, as well as an increase in one unit of RHmean is associated with an increase of 1.5 times the number of cases. This result corroborates with that found by Auler et al. (2020) when analyzing the association between meteorological variables and the case numbers for the São Paulo city.

The other significant associations found in our work, for the zero lag, show that the reduction of Tmax, RHmin, and WS increases the number of new cases. This was also found by Auler et al. (2020), who points out that for extreme events, Tmax and RHmin showed negative associations with the contamination numbers. Similar associations were observed in our results for the other lags.

Regarding the number of deaths, the results of the adjusted negative binomial regression model show that, for the zero lag, the increase in Tmean and Pmax, increases 5 and 3.31 times the number of deaths, respectively. Ma et al. (2020) and Bashir et al. (2020) also found a positive association between the death numbers and average temperature. Concerning atmospheric pressure, in situations of high pressure and low 
wind speed, pollutants remain on the surface of a given location, being prevented from spreading to higher regions in the atmosphere (BAUMBACH et al., 2018), that facilities the local virus transmission, due to a higher concentration of aerosols present. Still considering the zero lag, Pmean showed a negative association for the death numbers. There are still no studies that discuss the associations of deaths by COVID 19 with variations in atmospheric pressure. Future studies should analyze atmospheric pressure and pollution, in addition to the other variables, to better elucidate the aggravating conditions.

For the lags 10 and 15 (Table 4), Pmean and Tmin showed positive associations with the number of deaths. The opposite was observed for the zero lag. The associations between meteorological variables and the number of deaths and new cases caused by COVID19 are not yet clear and may be different from what is recommended by the literature on other viruses caused by other coronaviruses. The complexity of the association between meteorological variables and mortality and new cases of contamination by COVID19 should be better analyzed for each microclimate and location, as mentioned by Auler et al. (2020). We can consider that the nature of the associations may not be linear, as tested in the model proposed in this work, and then new associations between temperature, relative humidity, local pressure, and wind speed can be better explored.

\section{CONCLUSIONS}

This preliminary study on the city of São Paulo, Brazil, explored the associations between meteorological variables and the daily number of cases of infected people and the daily number of deaths, using the initial data related to the pandemic generated by COVID19. The results indicate temperature and relative humidity are important variables to identify meteorological conditions that lead to an increase in the number of deaths and contamination by the virus.

The negative binomial regression model presented results similar to the results presented by researchers from China, Brazil, and the United States. However, there is a need for further investigation concerning the analyzed variables and also about air pollution, which may be related to the different atmospheric pressure and wind speed conditions. Variations in meteorological variables may also be related to the process of contamination and lethality of the disease, as extreme weather events may be related to the number of contamination and deaths.

Therefore, this study agrees with observed by some researchers about associations between meteorological variables and numbers related to COVID19, related to the contamination and lethality dynamics of the new coronavirus, that must be better explored to collaborate with useful information to the public prevention policies.

\section{REFERENCES}

AHMADI, M.; SHARIFI, A.; DOROSTI, S.; GHOUSHCHI, S. J.; GHANBARI, N.. Investigation of effective climatology parameters on COVID-19 outbreak in Iran. Science of the Total Environment, v.729, 2020. DOI:

http://doi.org/10.1016/i.scitotenv.2020.138705
ALTAMIMI, A.; AHMED, A. E.. Climate factors and incidence of Middle East respiratory syndrome coronavirus. J. Infect. Public Health, v.13, n.5, p.704-708, 2020. DOI: http://doi.org/10.1016/i.jiph.2019.11.011 
AULER, A. C.; CÁSSARO, F. A. M.; SILVA, V. O.; PIRES, L. F.. Evidence that high temperatures and intermediate relative humidity might favor the spread of COVID-19 in tropical climate: A case study for the most affected Brazilian cities. Science of the Total Environment, v.729, 2020. DOI: https://doi.org/10.1016/j.scitotenv.2020.139090

BASHIR, M. F.; MA, B.; BILAL; KOMAL, B.; BASHIR, M. A.; TAN, D.; BASHIR, M.. Correlation between climate indicators and COVID-19 pandemic in New York, USA. Science of the Total Environment, v.728, n.138835, 2020. DOI: https://doi.org/10.1016/j.scitotenv.2020.138835

BAUMBACH, M.; BRUSCHE, N.. Condições Atmosféricas que Favorecem a Concentração de Poluentes no Sul do Brasil. Rev. Bras. Meteorol., v.33, n.2, p.269-278. 2018. DOI: https://doi.org/10.1590/0102-7786332006

BRASIL. Brasil confirma primeiro caso da doença. Brasília: Ministério da Saúde, 2020.

CHAN-YEUNG, M.; XU, R.. SARS: epidemiology. Respirology, v.8, p.9-14, 2003. DOI: http://doi.org/10.1046/j.14401843.2003.00518.x

CODATO, G.; OLIVEIRA, A. P.; SOARES, J.; ESCOBEDO, J. F.; GOMES, E. N.; DAL PAI, A.. Global and diffuse solar irradiances in urban and rural areas in southeast Brazil. Theor Appl Climatol, v.93, p.57-73, 2008.

CHINAZZI, M.; DAVIS, J. T.; AJELLI, M.; GIOANNINI, C.; LITVINOVA, M.; MERLER, S.; PIONTTI, A. P. Y.; MU, K.; ROSSI, L.; SUN, K.; VIBOUD, C.; XIONG, X.; YU, H.; HALLORAN, M. E.; LONGINI JUNIOR, I. M.; VESPIGNANI, A.. The effect of travel restrictions on the spread of the 2019 novel coronavirus (COVID-19) outbreak. Science, v.368, n.6489, p.395-400, 2020. DOI: http://doi.org/10.1126/science.aba9757

FICETOLA, G. F.; RUBOLINI, D.. Climate affects global patterns of COVID-19 early outbreak dynamics. MedRxiv: The preprint server for health sciences. 2020. DOI: https://doi.org/10.1101/2020.03.23.20040501

JAAKKOLA, K.; SAUKKORIIPI, A.; JOKELAINEN, J.; JUVONEN, R.; KAUPPILA, J.; VAINIO, O.; ZIEGLER, T.; RÖNKKÖ, E.; JAAKKOLA, J. J.K.; IKÄHEIMO, T. M.. Decline in temperature and humidity increases the occurrence of influenza in cold climate. Environ. Health., v.13, n.22, 2014. DOI: https://doi.org/10.1186/1476-069X-13-22

JO, E. J.; LEE, W. S.; JO, H. Y.; KIM, C. H.; EOM, J. S.; MOK, J. H.; KIM, M. H.; LEE, K.; KIM, K. U.; LEE, M. K.; PARK, H. K.. Effects of particulate matter on respiratory disease and the impact of meteorological factors in Busan, Korea. Respiratory Medicine, v.124, p.79-87, 2017. DOI: https://doi.org/10.1016/i.rmed.2017.02.010

GUPTA, R.; GIL-ALANA, L. A.; YAYA, O. S.. Do sunspot numbers cause global temperatures? Evidence from a frequency domain causality test. Appl. Econ., v.47, p.798808, 2015. DOI:

https://doi.org/10.1080/00036846.2014.980575

HUANG, C.; WANG, Y.; LI, X.; REN, L.; ZHAO, J.; HU, Y.; ZHANG, L.; FAN, G.; XU, J.; GU, X.; CHENG, Z.; YU, T.; XIA, J.; WEI, Y.; WU, W.; XIE, X. ; YIN, W. ; LI, H.; LIU, M.; XIAO, Y.;
GAO, H. ; GUO, L.; XIE, J.; WANG, G.; JIANG, R.; GAO, Z.; JIN Q.; WANG, J. ; CAO, B.. Clinical features of patients infected with 2019 novel coronavirus in Wuhan, China. The Lancet, v.395, p.497-506, 2020.DOI: https://doi.org/10.1016/S01406736(20)30183-5

IBGE. Instituto Brasileiro de Geografia e Estatística. Cidades e Estados. Rio de Janeiro: IBGE, 2019.

INMET. Instituto Nacional de Meteorologia. Estações e Dados. Brasília: INMET, 2020.

KAMPF, G.; TODT, D.; PFAENDER, S.; STEINMANN, E. Persistence of coronaviruses on inanimate surfaces and their inactivation with biocidal agents. J. Hosp. Infect., v.104, p.246-251, 2020. DOI:

https://doi.org/10.1016/j.jhin.2020.01.022

LAI, M. M.; CAVANAGH, D.. The molecular Biology of Coronovirus. Advances in Virus Research, v.48, p.1-100, 1997. DOI: https://doi.org/10.1016/S0065-3527(08)60286-9

LOWEN, A. C.; MUBAREKA, S.; STEEL, J.; PALESE, P.. Influenza virus transmission is dependent on relative humidity and temperature. Plos Pathog, v.3, n.10, p.1470-1476, 2007. DOI: https://doi.org/10.1371/journal.ppat.0030151

MA, Y.; ZHAO, Y.; LIU, J.; HE, X.; WANG, B. ; FU, S.; YAN, J.; NIU, J.; ZHOU, J.; LUO, B.. Effects of temperature variation and humidity on the death of COVID-19 in Wuhan, China. Science of The Total Environment, v.724, 2020. DOI: https://doi.org/10.1016/j.scitotenv.2020.138226

OLIVEIRA, A. P.; BORNSTEIN, R. D.; SOARES, J.. Annual and diurnal wind patterns in the city of São Paulo. Water, Air \& Soil Pollution: Focus, v.3, p.3-15, 2003.

OLIVEIROS, B.; CARAMELO, L.; FERREIRA, N. C.; CARAMELO, F.. Role of temperature and humidity in the modulation of the doubling time of COVID-19 cases. MedRxiv: The Preprint Server for Health Sciences. 2020. DOI: https://doi.org/10.1101/2020.03.05.20031872

PAULOSE, F.; MATHEW, A.; GEORGE, G.. GPS/GSM Based Embedded System for Atmospheric Boundary Layer Profiling and Weather Monitoring. International Journal of Science and Research (IJSR), v.3, n.9, p.1596-1601, 2014.

PECl, A.; WINTER, A.-L.; LI, Y.; GNANESHAN, S.; LIU, J.; MUBAREKA, S.; GUBBA, Y. J. B.. Effects of absolute humidity, relative humidity, temperature, and wind speed on influenza activity in Toronto, Ontario, Canada. Appl Environ Microbiol, v.85, n.e02426-18, 2019. DOI: https://doi .org/10.1128/AEM.02426-18

PRATA, D. N.; RODRIGUES, W.; BERMEJO, P. H.. Temperature significantly changes COVID-19 transmission in (sub) tropical cities of Brazil. Science of the Total Environment, v.729, n.138862, 2020. DOI: https://doi.org/10.1016/j.scitotenv.2020.138862

QI, H.; XIAO, S.; SHI, R.; WARD, M. P.; CHEN, Y.; TU, W; SU, Q.; WANG, W.; WANG, X.; ZHANG, Z.. COVID-19 transmission in Mainland China is associated with temperature and humidity: A time-series analysis, Science of the Total Environment, v.728, n.138778, 2020. DOI: https://doi.org/10.1016/j.scitotenv.2020.138778 
QU, J.; WICKRAMASINGHE, C.. SARS, MERS and the sunspot cycle. Current Science, v.113, n.8, p.1501, 2017.

R CORE TEAM. R: A language and environment for statistical computing. Vienna: R Foundation for Statistical Computing, 2020.

ROUSSEL, M.; PONTIER, D.; COHEN, J. M.; LINA, B.; FOUCHET, D.. Quantifying the role of weather on seasonal influenza. BMC Public Health, v.16:441, 2016. DOI: https://doi.org/10.1186/s12889-016-3114-x

SHI, P.; DONG, Y.; YAN, H.; LI, X.; ZHAO, C.; LIU, W.; HE, M.; TANG, S.; XI, S.. The impact of temperature and absolute humidity on the coronavirus disease 2019 (COVID-19) outbreak - evidence from China. MedRxiv: The Preprint Server for Health Sciences, 2020. DOI: http://doi.org/10.1101/2020.03.22.20038919

SUNDELL, N.; ANDERSSON, L. M.; BRITTAIN-LONG, R.; LINDH, M.; WESTIN, J.. A four year seasonal survey of the relationship between outdoor climate and epidemiology of viral respiratory tract infections in a temperate climate. Journal of clinical virology, v.84, p.59-63, 2016. DOI: https://doi.org/10.1016/j.jcv.2016.10.005

SEADE. Fundação Sistema Estadual de Análise de Dados Estatísticos. Coronavirus: Casos em SP. São Paulo: Secretaria de Estado da Saúde, 2020.

SOBRAL, M. F. F.; DUARTE, G. B.; SOBRAL, A. I. G. P.; MARINHO, M. L. M.; MELO, A. S.. Association between climate variables and global transmission of SARS-CoV-2.
Science of the Total Environment, v.729, n.138997, 2020. DOI: https://doi.org/10.1016/i.scitotenv.2020.138997

WANG, C.; HORBY, P. W.; HAYDEN, F. G.; GAO, G. F.. A novel coronavirus outbreak of global health concern. The Lancet, v.395, n.10223, p.470-473, 2020a. DOI: https://doi.org/10.1016/S0140-6736(20)30185-9

WANG, M.; JIANG, A.; GONG, L.; LUO, L.; GUO, W.; LI, C.; CHEN, Y. Temperature significant change COVID-19 Transmission in 429 cities. MedRxiv: The Preprint Server for Health Sciences, 2020b. DOI: https://doi.org/10.1101/2020.02.22.20025791

WHO. Word Health Organization. Coronavirus disease 2019 (COVID -19): Situation Report-51. WHO, 2020a.

WHO. Word Health Organization. WHO characterizes COVID-19 as a pandemic. WHO, 2020b.

WHO. Word Health Organization. MERS situation update. WHO, 2019.

YANG, W.; ELANKUMARAN, S.; MARR, L. C.. Relationship between humidity and influenza $A$ viability in droplets and implications for influenza's Seasonality. PLoS ONE, v.85, n.6, 2012. DOI: https://doi.org/10.1371/journal.pone.0046789

ZAMBRANO-MONSERRATE, M. A.; RUANO, M. A; SANCHEZALCALDE, L.. Indirect effects of COVID-19 on the environment. Science of the Total Environment, v.728, n.138813, 2020. DOI: https://doi.org/10.1016/j.scitotenv.2020.138813

A CBPC - Companhia Brasileira de Produção Científica (CNPJ: 11.221.422/0001-03) detém os direitos materiais desta publicação. Os direitos referem-se à publicação do trabalho em qualquer parte do mundo, incluindo os direitos às renovaç̃oses, expansões e disseminações da contribuiç̃o, bem como outros direitos subsidiários. Todos os trabalhos publicados eletronicamente poderão posteriormente ser publicados em coletâneas impressas sob coordenação da Sustenere Publishing, da Companhia Brasileira de Produção Científica e seus parceiros autorizados. Os (as) autores (as) preservam os direitos autorais, mas não têm permissão para a publicação da contribuição em outro meio, impresso ou digital, em português ou em tradução. 